\title{
Characterization of hot water extract from Korean deer velvet antler (Cervus canadensis Erxleben)
}

\author{
Su-Hyeon Kim ${ }^{1}$, Kashif Ameer ${ }^{2,3}$, Jun-Hyun $\mathrm{Oh}^{4}$, Mi-Kyung Park ${ }^{1,5 *}$ \\ ${ }^{1}$ School of Food Science and Biotechnology, Kyungpook National University, Daegu 41566, Korea \\ ${ }^{2}$ Department of Food Science and Technology and BK 21 Plus Program, Graduate School of Chonnam National University, \\ Gwangju 61186, Korea \\ ${ }^{3}$ Institute of Food and Nutritional Sciences, PMAS-Arid Agriculture University, Rawalpindi 46300, Pakistan \\ ${ }^{4}$ Deparment of Plant and Food Sciences, Sangmyung University, Choenan 31066, Korea \\ ${ }^{5}$ Food and Bio-Industry Research Institute, Kyungpook National University, Daegu 41566, Korea
}

\author{
국내산 녹용 열수추출물의 특성 \\ 김수현 ${ }^{1} \cdot$ Kashif Ameer ${ }^{2,3}$ · 오준현 ${ }^{4}$ 박미경 ${ }^{1,5 *}$ \\ ${ }^{1}$ 경북대학교 식품공학부, ${ }^{2}$ 전남대학교 국제협력본부, \\ ${ }^{3}$ Institute of Food and Nutritional Sciences, PMAS-Arid Agriculture University, \\ 4상명대학교 식물식품공학과, ${ }^{5}$ 경북대학교 식품생물산업연구소
}

\begin{abstract}
Velvet antlers (VA) sourced from red (Cervus elaphus), sika (C. nippon), and elk (C. canadensis) deer have become increasingly popular in Chinese, Korean and Japanese traditional and oriental medicines as supplements for disease prevention. Therefore, this study aimed to determine the chemical components (proximate composition, amino, uronic, and sialic acids) and to characterize the bacterial profile of VA extract. The yield and contents of uronic and sialic acids extracted from VA at $98-100{ }^{\circ} \mathrm{C}$ for $29-36$ sec were determined to be $40.71 \%, 28.06 \mathrm{mg} / \mathrm{g}$ and $0.73 \mathrm{mg} / \mathrm{g}$, respectively. Overall, proximate parameters were higher in extracts recovered at $100{ }^{\circ} \mathrm{C}$ compared with $90^{\circ} \mathrm{C}$, and these parameters were: moisture $(4.66 \%)$, crude protein $(86.63 \%)$, crude fat $(3.23 \%)$, crude ash $(4.1 \%)$, and carbohydrate content (5.43\%). Alanine was the most abundant among the identified amino acids. Analysis of 16S rRNA sequence identified 12 bacterial species, including seven gram-positive and five gram-negative bacteria. Among all bacteria, Chryseobacterium indologenes, Shigella flexneri ATCC 29903, Staphylococcus equorum, Staphylococcus xylosus, Staphylococcus succinus, and Vagococcus fluvialis had $100 \%$ identity in the VA extract. The morphology of $C$. indologene, S. flexneri ATCC 29903, and V. fluvialis was bacilli, whereas S. equorum, S. succinus, and S. xylosus were cocci.
\end{abstract}

Key words : velvet antler, chemical composition, characterization, amino acid, bacteria

Introduction

The demand of natural food constituents derived from animal or plan origin has escalated on global scale owing to increased awareness level in health-conscious people (Earnest et al., 2015). Among historically used medicines of animal-origin, velvet antler (VA) usage could be traced back to ancient times of more than 2,000 years ago and exhibit

*Corresponding author. E-mail : parkmik@knu.ac.kr, Phone :+82-53-950-5776, Fax : +82-53-950-6772

Received 10 July 2020; Revised 18 September 2020; Accepted 12 October 2020.

Copyright (c) The Korean Society of Food Preservation.

This is an Open Access article distributed under the terms of the Creative Commons Attribution Non-Commercial License (http://creativecommons.org/licenses/by-nc/4.0) which permits unrestricted non-commercial use, distribution, and reproduction in any medium, provided the original work is properly cited. 
several pharmacological benefits for immune, cardiovascular, nervous and reproductive systems and are used frequently to develop functional foods, nutraceutical supplements and other medicinal products (Jang et al., 2020; Zhao et al., 2016). Bioactive compounds from animal sources include essential oils, vitamins, minerals, dietary fiber, peptides, protaglandinds, glycoaminoglycans, proteins and fatty acids (Cheng et al., 2017). All these bioactive compounds are widely employed in pharmaceutical sector to prepare medicines and supplements to mitigate lifestyle related disorders (Sui et al., 2014; Zhao et al., 2016).

Animals of Cervidae family like elk, deer, moose and caribou usually have VA in the form of whole cartilaginous antler at pre-calcified growth stage. Global supply of VA is usually met by antlers originated from Red deer, Sika deer, Alk and Wapiti (Elaphurus davidianus) (Huo et al., 2014). In historical recorded, Chinese traditional medicine has a detailed account of medicinal uses of VA with name of Pinyin Lu Rong for treating deficiency syndromes and most notable deer species in this regard include Red deer and Sika deer (Zhao et al., 2016). In recent years, VA's sourced from Red and Sika deer have become increasingly popular in China, Korea and Japan in terms of supplements usage for disease prevention (Jeon et al., 2009). VA usually consumed orally and according to recently published reports, the total production of VA on global scale was 1,300/year and demand is increasing gradually every year. Hence, the researchers are actively exploring new bioactive compounds from VA and VA extraction methods and its properties (Huo et al., 2014; Zhao et al., 2016).

VA product is usually sold as nutraceutical in encapsulated form through health food stores and pharmacies. Mostly, the pharmacies and health food stores set their own quality standards for VA products. In this regard, product safety concerns include bacterial contamination (E. coli, Salmonella spp.) or physical contamination like dander (Huo et al., 2014). Consistent VA product safety and quality parameters increase processor reputation and allows to get market penetration. Moreover, VA product safety is also an important aspect of good manufacturing practices in processing plants (Cooney, 2001). Siliac acid is categorized as an acidic sugar and is member of family of derivative compounds and most commonly also known as $N$ acetylneuraminic acid. Sialic acids are widely found in distributive manner in animal tissues, mostly in glycoproteins and gangliosides (Dhar et al., 2019). In terms of glycobiology, the sialic acid forms glycan chains and plays a vital role on cell surfaces and soluble proteins and is involved in tissues structural configuration and modulation of variety of normal physiological processes (Varki, 2008). Similalry, uronic acid is also included in class of sugar acids. Uronic acid is widely distributed in liver and adipose tissues. In humans, uronic acid pathway is involved in glucose metabolism as an alternative oxidative pathway and catalyzes conversion of glucose to glucuronic acid (Garron et al., 2010). Major function of uronic acid pathway is to synthesize D-glucuronic acid which has role in detoxification of foreign chemicals and synthesis of mucopolysaccharides (Zhao and Brasier, 2019).

Therefore, this study was aimed to analyze the proximate composition (moisture, crude protein, crude fat, crude ash, carbohydrate) of hot water VA extract and total yield and bioactive compounds (uronic and sialic acids) were determined at two different extraction temperatures $\left(90\right.$ and $\left.100^{\circ} \mathrm{C}\right)$ and extraction times (12, 24 and $36 \mathrm{~h})$. Moreover, the amino acid profile of VA extract extracted at $24 \mathrm{~h}$ were evaluated at 90 and $100^{\circ} \mathrm{C}$ followed by identification of the microbiological profile of pathogenic bacteria in VA.

\section{Materials and methods}

\section{Materials}

VA of deer (Cervus canadensis Erxleben), raised in Korean local farm, was supplied by the Deer Cluster (Cheongju, Korea). Dried VA samples subjected to sectioning at thickness of 1-3 mm followed by grinding using a grinder into fine powder (160-180 mesh). Equal mixture of powder obtained from top, middle, and bottom sections of meshed VA was obtained, and was further used for extraction. Analytical grade chemicals were employed in this study.

\section{Extraction and purification of VA}

VA and distilled water were added to a round- bottom flask and extracted with a reflux extractor was used for VA extraction as per described method (Ameer et al., 2017). No stirring bar was used. For extraction, an aliquot of VA mixture $(5.625 \mathrm{~g})$ was mixed with $1 \mathrm{~L}$ distilled water (DW) at specified extraction conditions of 90 and $100^{\circ} \mathrm{C}$ tem- 
peratures at extraction times of 12,24 and $36 \mathrm{~h}$ at each temperature. After extraction, the extracts were filtered through a Whatman filter paper No. 4 and centrifuged at $4,005 \times g$ for $30 \mathrm{~min}$. The VA extract was concentrated using a rotary evaporator (N-2110, Sunileyela, Sungnam, Korea), followed by freeze-drying (Ilsinbiobase, Dongduchen, Korea) and storage at $-20^{\circ} \mathrm{C}$ prior to use.

\section{Proximate analysis}

The general proximate analysis procedures of moisture, crude protein, crude fat, crude ash, and carbohydrate were performed following the AOAC standard methods (AOAC, 1996). The moisture content was measured by drying at 10 $5^{\circ} \mathrm{C}$ in a drying oven. The crude protein content was determined by semi-micro Kjeldahl method (AOAC, 1996).

\section{Determination of extraction yield}

The extraction yield was calculated by weighing the dried samples obtained after freeze-drying according to the Eq. 1 given below.

$$
\begin{aligned}
& \text { Extraction yield }(\%)= \\
& \frac{\text { Freeze }- \text { dried extract weight }(\mathrm{g})}{\text { VA powder weight }(\mathrm{g})} \times 100
\end{aligned}
$$

\section{Determination of sialic and uronic acids contents}

Sialic acid content was determined using the thiobarbituric acid (TBA) assay and $\mathrm{N}$-acetylneuraminic acid (Sigma-Aldrich, St. Louis, MO, USA) was used as a standard (Warren, 1959). An aliquot of $0.2 \mathrm{~mL}$ of VA extract was mixed with $0.1 \mathrm{~mL}$ periodate solution for $20 \mathrm{~min}$ at room temperature. After that, $1 \mathrm{~mL}$ of arsenite and $3.0 \mathrm{~mL}$ of TBA solutions were added and reacted at boiling temperature for $15 \mathrm{~min}$ followed by standing time of $5 \mathrm{~min}$ to cool down. An aliquot of $1 \mathrm{~mL}$ of the reaction mixture was added into $1 \mathrm{~mL}$ of cyclohexanone and centrifuged at $11,124 \times g$ for $3 \mathrm{~min}$. The optical density of the supernatant at $549 \mathrm{~nm}$ was measured using a spectrophotometer (UVmini 1240, Shimadzu, Kyoto, Japan). Sialic acid of VA extract was also determined using a HPLC equipped with Phenomenex Luna $\mathrm{C}_{18}$ column $(4.5 \mathrm{~mm} \times 250 \mathrm{~mm}, 5 \mu \mathrm{m}$ pore size, Phenomenex Co., Torrance, CA, USA) and multi fluorescence detector (Waters 2475, Minford, MA, USA). The detailed HPLC conditions for sialic acid determination are presented in Table 1.

Uronic acid content was determined by carbazole reaction using a 96-well plate according to the described method of Cesaretti et al. (2003). The sample was added into a 96-well plate followed by addition of sulfuric acid into the well. The plate was placed in an oven at $100^{\circ} \mathrm{C}$ for $10 \mathrm{~min}$ and cooled down at room temperature for $5 \mathrm{~min}$. Afterwards carbazole solution $(0.125 \%)$ was added and the plate was placed in an oven at $100^{\circ} \mathrm{C}$ for $10 \mathrm{~min}$, and cooled down at room temperature for $15 \mathrm{~min}$. The optical density at $550 \mathrm{~nm}$ was measured using a spectrophotomer (UVmini 1240, Shimadzu).

\section{Analysis of amino acid profile}

Approximately $0.1 \mathrm{~g}$ of $5 \%$ trichloroacetic acid was added to freeze-dried VA extracts and diluted 10 times using distilled water (Jeon et al., 2009). Then, the supernatant was collected by centrifugation at $11,124 \times g$ for $10 \mathrm{~min}$, and filtered through a membrane filter $(0.45 \mu \mathrm{m})$. The amino acid analysis of the filtrate was performed using an amino acid analyzer (L-8900, Hitachi, Tokyo, Japan).

\section{Bacterial identification of VA extract}

VA extract sample (25 g) was aseptically weighed into filtered stomacher bags and homogenized with $225 \mathrm{~mL}$ $(0.1 \% \mathrm{w} / \mathrm{v})$ peptone water for $3 \mathrm{~min}$. Samples were then serially diluted and $1 \mathrm{~mL}$ of dilution was incorporated into blood agar plate (BAP) followed by incubation at $37^{\circ} \mathrm{C}$ for 10-26 h (Payment et al., 1994). All isolates were separated based on their colony formation, time and color. Separated colony was further purified by streak plating. Identification

\begin{tabular}{|c|c|}
\hline \multicolumn{2}{|r|}{ Conditions } \\
\hline Column & $\begin{array}{l}\text { Phenomenex Luna } C_{18}(2) 100 \AA(250 \times 4.6 \\
\mathrm{mm}, 5 \mu \mathrm{m})\end{array}$ \\
\hline Eluent & $\begin{array}{l}\mathrm{AcOH} / \mathrm{MeOH} / \mathrm{H}_{2} \mathrm{O}=0.05 / 25 / 75 \text { (isocratic } \\
\text { mode) }\end{array}$ \\
\hline Flow rate & $1.2 \mathrm{~mL} / \mathrm{min}$ \\
\hline Oven Temp. & $30^{\circ} \mathrm{C}$ \\
\hline Detector & Fluorescence ex. 373 nm, em. 448 nm \\
\hline Run time & $30 \mathrm{~min}$ \\
\hline
\end{tabular}

Table 1. HPLC conditions for analysis of sialic acid 
was performed by analyzing the $16 \mathrm{~S}$ rRNA sequence and detecting the homology of the nucleotide sequences in BLAST of National Center for Biotechnology Information (NCBI) (Mignard and Flandrois, 2006).

\section{Statistical analysis}

Statistical analysis was performed using Microsoft Office (ver. 2016, USA) and SAS software (ver. 8.0, SAS Institute Inc., Cary, NC, USA). Differences among means were analyzed using Duncan's Multiple Range Test (DMRT), and the significance level was defined at $\mathrm{p}<0.05$.

\section{Results and discussion}

\section{Proximate composition of VA extract}

Mostly, the pharmacies and health food stores set their own quality standards for VA products and chemical composition analysis allows to elucidate dynamic compositional and quantitative changes in VA extract for standardization (Cooney, 2001). Proximate composition of VA extract was analyzed and results are given in Table 2. Overall, the extracts recovered at $100^{\circ} \mathrm{C}$ temperature showed higher proximate parameters as compared to extracts recovered at $90^{\circ} \mathrm{C}$ temperature and these parameters were as: moisture (4.66\%), crude protein $(86.63 \%)$, crude fat $(3.23 \%)$, crude ash $(4.1 \%)$ and carbohydrate content (5.43\%). Actually, the crude fat content exhibited increasing tendency with corresponding rises in extraction temperature and time. This can be possibly attributed to the fact of increased mass transfer of solutes from matrix of VA mixture due to rises in extraction temperature (Ameer et al., 2017). Elevated tem- peratures have been reported to accelerate mass transfer of solutes from samples matrices irrespective of their origin. Moreover, reflux extraction at elevated temperature of $100^{\circ} \mathrm{C}$ resulted in higher amounts of crude fat due to water absorption resulting in dilution which consequently accelerated mass transfer rate (Onyeike and Oguike, 2003). These findings are in agreement with the previous findings of Jeon et al. (2009) who inferred that bone composition of antler may vary depending on specific antler farming region and weight specifications of the antler from that region.

\section{Effects on yield and content of uronic and sialic acid}

Sialic and uronic acids are found as glycosaminoglycans in VA extract (Huo et al., 2014). Therefore, the determination of sialic and uronic acids as biomarker may provide useful basic information for the association between structural properties and chemical composition during antler growth period, which should facilitate efficient production of high-quality antlers for food consumption and as pharmaceutical agents (Cooney, 2001). In this study, single factor experiments were carried out by keeping one variable constant and varying the second at different levels to determine the individual effects of variables on target responses (yield, uronic and sialic acid contents). The results tabulated in Table 3 showed that yield exhibited linear increases with corresponding rises in extraction time. At $90^{\circ} \mathrm{C}$ and $100^{\circ} \mathrm{C}$ extraction temperatures, the highest VA extract yield was $37.07 \%$ and $39.97 \%$, respectively at $36 \mathrm{~h}$ of extraction time. In case of uronic acid content, VA extract obtained at $90^{\circ} \mathrm{C}$ temperature showed linear rises and

Table 2. Proximate composition of velvet antler extract

\begin{tabular}{ccccccc}
\hline $\begin{array}{c}\text { Extraction } \\
\text { temperature }\left({ }^{\circ} \mathrm{C}\right)\end{array}$ & $\begin{array}{c}\text { Extraction time } \\
(\mathrm{h})\end{array}$ & $\begin{array}{c}\text { Moisture } \\
(\%)\end{array}$ & $\begin{array}{c}\text { Crude protein } \\
(\%)\end{array}$ & $\begin{array}{c}\text { Crude fat } \\
(\%)\end{array}$ & $\begin{array}{c}\text { Crude ash } \\
(\%)\end{array}$ & $\begin{array}{c}\text { Carbohydrate } \\
(\%)\end{array}$ \\
\hline \multirow{2}{*}{90} & 12 & $4.51 \pm 0.17^{2) \mathrm{ab} 3)}$ & $85.32 \pm 0.93^{\mathrm{a}}$ & $1.55 \pm 0.13^{\mathrm{a}}$ & $3.19 \pm 0.11^{\mathrm{a}}$ & $5.43 \pm 1.08^{\mathrm{c}}$ \\
& 24 & $4.53 \pm 0.20^{\mathrm{ab}}$ & $85.64 \pm 0.80^{\mathrm{a}}$ & $1.78 \pm 0.10^{\mathrm{b}}$ & $3.87 \pm 0.21^{\mathrm{b}}$ & $4.18 \pm 1.24^{\mathrm{bc}}$ \\
& 36 & $4.26 \pm 0.16^{\mathrm{a}}$ & $86.17 \pm 1.32^{\mathrm{a}}$ & $2.49 \pm 0.11^{\mathrm{d}}$ & $4.17 \pm 0.17^{\mathrm{c}}$ & $2.91 \pm 1.71^{\mathrm{ab}}$ \\
\hline & 12 & $4.66 \pm 0.12^{\mathrm{b}}$ & $85.55 \pm 1.03^{\mathrm{a}}$ & $2.14 \pm 0.06^{\mathrm{c}}$ & $3.43 \pm 0.13^{\mathrm{a}}$ & $4.22 \pm 1.34^{\mathrm{bc}}$ \\
& 24 & $4.63 \pm 0.10^{\mathrm{b}}$ & $86.12 \pm 0.68^{\mathrm{a}}$ & $2.78 \pm 0.10^{\mathrm{e}}$ & $3.86 \pm 0.20^{\mathrm{b}}$ & $2.61 \pm 0.83^{\mathrm{ab}}$ \\
& 36 & $4.49 \pm 0.14^{\mathrm{ab}}$ & $86.63 \pm 1.17^{\mathrm{a}}$ & $3.23 \pm 0.13^{\mathrm{f}}$ & $4.09 \pm 0.09^{\mathrm{bc}}$ & $1.1 \pm 0.87^{\mathrm{a}}$ \\
\hline
\end{tabular}

${ }^{1)}$ Carbohydrate content $(\%)=100-$ (Moisture + Crude protein + Crude fat + Crude ash).

${ }^{2)}$ Data are mean \pm SD $(\mathrm{n}=3)$.

${ }^{3)}$ Values followed by different letters $\left({ }^{\mathrm{a}-\mathrm{f}}\right)$ within a column are significantly different at $\mathrm{p}<0.05$ based on Duncan's multiple range test. 
Table 3. The yield and contents of sialic acid and uronic acid of velvet antler extract

\begin{tabular}{|c|c|c|c|c|}
\hline $\begin{array}{l}\text { Extraction temperature } \\
\left({ }^{\circ} \mathrm{C}\right)\end{array}$ & $\begin{array}{l}\text { Extraction time } \\
\text { (h) }\end{array}$ & $\begin{array}{l}\text { Yield } \\
(\%)\end{array}$ & $\begin{array}{c}\text { Uronic acid content } \\
(\mathrm{mg} / \mathrm{g})\end{array}$ & $\begin{array}{l}\text { Sialic acid content } \\
(\mathrm{mg} / \mathrm{g})\end{array}$ \\
\hline \multirow{3}{*}{90} & 12 & $31.52 \pm 0.77^{1) \mathrm{a} 2)}$ & $16.66 \pm 0.91^{\mathrm{ab}}$ & $0.36 \pm 0.04^{\mathrm{a}}$ \\
\hline & 24 & $33.26 \pm 1.10^{\mathrm{b}}$ & $21.03 \pm 0.30^{\mathrm{c}}$ & $0.49 \pm 0.03^{\mathrm{b}}$ \\
\hline & 36 & $37.07 \pm 1.05^{\mathrm{c}}$ & $28.06 \pm 3.17^{\mathrm{d}}$ & $0.56 \pm 0.04^{b}$ \\
\hline \multirow{3}{*}{100} & 12 & $34.45 \pm 0.52^{b}$ & $14.91 \pm 1.01^{\mathrm{a}}$ & $0.60 \pm 0.08^{\mathrm{bc}}$ \\
\hline & 24 & $39.29 \pm 0.60^{\mathrm{d}}$ & $22.68 \pm 1.84^{\mathrm{c}}$ & $0.73 \pm 0.11^{\mathrm{c}}$ \\
\hline & 36 & $39.97 \pm 1.21^{\mathrm{cd}}$ & $19.94 \pm 1.71^{\mathrm{bc}}$ & $0.60 \pm 0.10^{\mathrm{bc}}$ \\
\hline
\end{tabular}

${ }^{1)}$ Data are mean $\pm \mathrm{SD}(\mathrm{n}=3)$.

${ }^{2)}$ Values followed by different letters $\left({ }^{\mathrm{a}-\mathrm{d}}\right)$ within a column are significantly different at $\mathrm{p}<0.05$ based on Duncan's multiple range test.

maximum uronic acid content at $36 \mathrm{~h}$ was $28.06 \mathrm{mg} / \mathrm{g}$, while uronic acid content decreased at $36 \mathrm{~h}$ of extraction time and $100^{\circ} \mathrm{C}$ temperature. At $100^{\circ} \mathrm{C}$, maximum uronic acid content was $22.68 \mathrm{mg} / \mathrm{g}$ at $24 \mathrm{~h}$ of extraction time while increase in extraction time resulted in decline of uronic acid content. Standard curve for sialic acid ( $N$-acetylneuraminic acid) is shown in Fig. 1 which exhibited coefficient of regression of 99.75\%. HPLC chromatograms of selected concentrations of sialic acid standards and selected concentrations of velvet antler extract are shown in Fig. 2. Likewise, similar to uronic acid content, sialic acid content showed the same tendency and maximum sialic acid contents were $0.56 \mathrm{mg} / \mathrm{g}$ and $0.73 \mathrm{mg} / \mathrm{g}$ at 90 and $100^{\circ} \mathrm{C}$ temperatures, respectively. Conclusively in comparison with $90^{\circ} \mathrm{C}$ extraction temperature at $24 \mathrm{~h}$, the best extraction conditions were extraction temperature of $100^{\circ} \mathrm{C}$ at $24 \mathrm{~h}$ of extraction time.

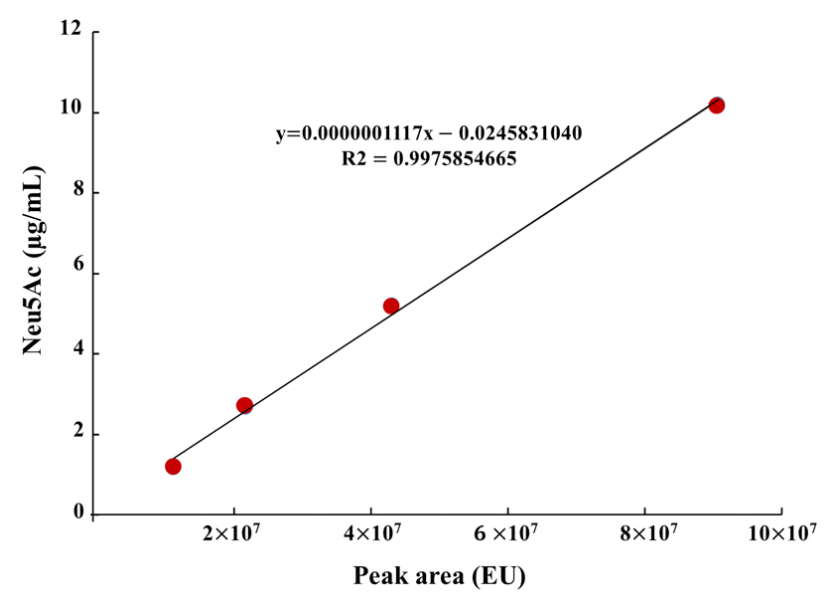

Fig. 1. Standard curve of $\mathrm{N}$-acetylneuraminic acid for quantification of sialic acid.
These extraction conditions led to recovery of higher yield (39.29\%), uronic acid content $(22.68 \mathrm{mg} / \mathrm{g})$, and sialic acid content $(0.73 \mathrm{mg} / \mathrm{g})$. Similar results have been reported by Jin et al. (2015) regarding hot water extraction of bioactive compounds from middle parts of deer antlers originated from New Zealand. Hot water extraction showed comparable extract yield (6.72\%) and sialic and uronic acids contents were $0.11 \mathrm{mg} / \mathrm{g}$ and $0.75 \mathrm{mg} / \mathrm{g}$ of solid Optimal conditions for $\mathrm{HE}$ were $90^{\circ} \mathrm{C}$ for $20 \mathrm{~h}$ with a solvent ratio of 1:29.34. Temperature played the pivotal role in case of extraction yield followed by solvent ratio which generally exerted significant effect on recovery of sialic and uronic acids. Similarly, in another report by Sunwoo et al. (1997), sialic and uronic acids yields were $0.16 \%(\mathrm{w} / \mathrm{w})$ and $0.35 \%$ $(w / w)$, respectively obtained from growing antlers of wapiti (Cervus elaphus).

\section{Amino acids profile of VA extract}

Amino acid content from two different VA extracts are shown in Table 4. Arginine, aspartic acid and serine were not detected in VA extract obtained from both extracts at $90^{\circ} \mathrm{C}$ and $100^{\circ} \mathrm{C}$ temperatures at extraction time of $24 \mathrm{~h}$. Total amino acid content was found to be higher in the extract recovered at $90^{\circ} \mathrm{C}(22.84 \mathrm{mg} / \mathrm{g})$ as compared to $100^{\circ} \mathrm{C}$ extract $(8.48 \mathrm{mg} / \mathrm{g})$. Alanine, glycine, leucine, phenylalanine, hydroxyproline and valine were the predominant amino acids among all VA extracts and these accounted for the $33-37 \%$ of the total amino acid content. This can be attributed to the presence of collagen in large amounts in VA structural matrix. It was evident that $90^{\circ} \mathrm{C}$ temperature led to the increased recovery of the hydroxyproline in 
Table 4. Amino acid composition of velvet antler extract

\begin{tabular}{|c|c|c|}
\hline \multirow{2}{*}{$\begin{array}{l}\text { Amino acid } \\
(\mathrm{mg} / \mathrm{g})\end{array}$} & $90^{\circ} \mathrm{C}$ & $100^{\circ} \mathrm{C}$ \\
\hline & $24 \mathrm{~h}$ & $24 \mathrm{~h}$ \\
\hline Alanine & 3.73 & 1.30 \\
\hline Arginine & $\mathrm{ND}^{1)}$ & $\mathrm{ND}$ \\
\hline Aspartic aid & ND & ND \\
\hline Cystine & 0.41 & 0.08 \\
\hline Glutamic acid & 0.36 & 0.05 \\
\hline Glycine & 2.48 & 1.21 \\
\hline Histidine & 0.19 & 0.11 \\
\hline Hydroxyproline & 0.35 & 0.27 \\
\hline Isoleucine & 0.48 & 0.08 \\
\hline Leucine & 3.23 & 0.55 \\
\hline Lysine & 0.94 & 0.10 \\
\hline Methionine & 0.95 & 0.16 \\
\hline Phenylalanine & 1.77 & 0.29 \\
\hline Proline & 0.28 & 0.04 \\
\hline Serine & ND & ND \\
\hline Threonine & 0.05 & 0.01 \\
\hline Tyrosine & 0.73 & 0.13 \\
\hline Valine & 1.74 & 0.40 \\
\hline Total & 22.84 & 8.48 \\
\hline
\end{tabular}

${ }^{1)} \mathrm{ND}$, not detected.

comparison with extraction temperature of $100^{\circ} \mathrm{C}$. In case of proline, $90^{\circ} \mathrm{C}$ temperature resulted in higher content in VA extract $(0.28 \mathrm{mg} / \mathrm{g})$ in comparison with VA extract obtained at $100^{\circ} \mathrm{C}$ temperature $(0.04)$. Kim et al. (2002) has reported that glutamic acid, proline, aspartic acid and glycine constituted the major proportion of amino acid profile of VA from both Elk and Sika deer. It was also implied that composition of the amino acid may be an indicative of quality of the VA and amino acid profile is influenced by the elongation, mineralization, growth period and section specificity of the VA.

\section{Bacterial characterization of the VA extract}

Pathogenesis of human diseases may rise from the microbial colonization of various human organs and especially bacteria may proliferate from the natural products such as,
(A)

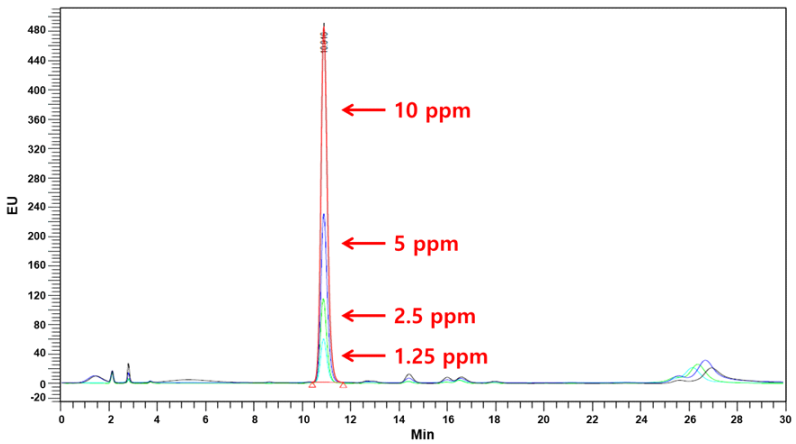

(B)

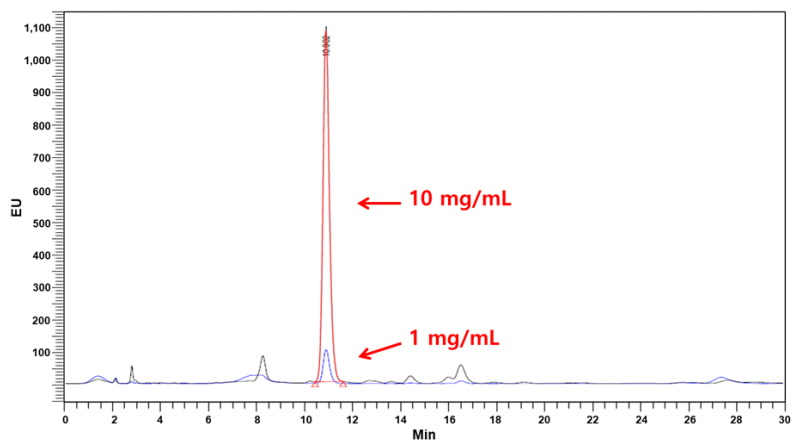

Fig. 2. HPLC chromatograms of (A) sialic acid standard and (B) velvet antler extract.

extracts of plant or animal origins and infusions. Therefore, the bacterial flora need to be identified in the extracts obtained from both plants and animals to have overview of the pathogenic and non-pathogenic bacterial types (Barbour et al., 1997). As the VA extracts are usually employed for development of processed and functional foods/health promoting supplements, therefore, the bacteria may get introduced into the processing lines or through other food ingredients by coming into contact with extracts or infusions (Barbour et al., 1997). Keeping this in view, the VA extract was analyzed for pathogenic bacteria present in VA extract (Table 5). Among all bacteria, Chryseobacterium indologenes, Shigella flexneri ATCC 29903, Staphylococcus equorum, Staphylococcus xylosus, Vagococcus fluvialis and Staphylococcus succinus demonstrated 100\% identities in the VA extract. The morphological status of $C$. indologene, S. flexneri ATCC 29903 and V. fluvialis was Bacilli, while Cocci was the morphology of $S$. equorum, S. succinus and S. xylosus. While other identified bacteria were in the order as given; Bacillus amyloliquefaciens, Escherichia fergusonii 
Table 5. Identified bacteria and their characteristics isolated from velvet antler

\begin{tabular}{lccc}
\hline \multicolumn{1}{c}{ Bacteria } & Identities (\%) & Gram & Morphology \\
\hline Bacillus amyloliquefaciens & 99 & + & Bacilli \\
Chryseobacterium indologenes & 100 & - & Bacilli \\
Escherichia fergusonii ATCC 35469 & 99 & - & Bacilli \\
Klebsiella oxytoca ATCC 13182 & 99 & + & Bacilli \\
Macrococcus caseolyticus ATCC 13548 & 99 & - & Cocci \\
Mannheimia granulomatis ATCC 49244 & Bacilli \\
Shigella flexneri ATCC 29903 & 97 & - & Bacilli \\
Staphylococcus equorum & 100 & + & Cocci \\
Staphylococcus succinus & 100 & + & Cocci \\
Staphylococcus warneri & 100 & Cocci \\
Staphylococcus xylosus & 99 & Cocci \\
Vagococcus fluvialis & 100 & + & Bacilli \\
\hline
\end{tabular}

ATCC 35469, Klebsiella oxytoca ATCC 13182, Macrococcus caseolyticus ATCC 13548 and Staphylococcus warneri showed 99\% identities from the VA extract followed by Mannheimia granulomatis ATCC 49244 (97\% identity). The bacterial flora identified from the VA extract may serve as the reference database regarding microbiological assessment studies of the VA extract from deer. Furthermore, the identified bacterial types were characterized with respect to gram staining (either positive or negative) and morphology. As shown in Table 5, five bacteria including Chryseobacterium indologenes, Escherichia fergusonii ATCC 35469, Klebsiella oxytoca ATCC 13182, Mannheimia granulomatis ATCC 49244, and Shigella flexneri ATCC 29903 were idneified as gram (-) bacteria. Contrary, all other bacteria were identified as gram (+) bacteria. All gram (-) bacteria had rod shape whereas gram $(+)$ bacteria consisted of cocci and rod shape. These analysis data will provide the microbiological profile of VA extract for using as a basic resource. Even though 6 species were identified as pathogenic bacteria in VA extract, no colony-forming ability from the entire range of identified bacterial species was observed in the VA extract. Kumar et al. (2014) have characterized the bacteria from extract of the Boerhaavia diffusa plant. Among all bacteria, Aeromonas hydrophila, Pseudomonas fluorescens and Flavobacterium branchiophilum were found to be pathogenic bacteria.
In conclusion, velvet antler (VA) has been known since ancient times for its pharmaceutical and health benefits in traditional and oriental medicine. Some of the prominent pharmaceutical functions include anti-inflammatory, antiaging, anti-arthritis effects along with enhancement of the cognitive and brain activities. In this study, analysis of chemical components of VA extract (having pharmaceutical importance, such as amino acids, uronic and sialic acids) was carried out. Moreover, bacterial profile of VA extract was characterized. Results showed that after reflux extraction, the yield and contents of uronic acid and sialic acid of the VA extract were determined to be $39.29 \%, 22.68$ $\mathrm{mg} / \mathrm{g}$ and $0.73 \mathrm{mg} / \mathrm{g}$, respectively at $100^{\circ} \mathrm{C}$ temperature and $24 \mathrm{~h}$ extraction time. The contents of moisture, crude protein, crude fat, and crude ash of VA extract were $4.26-4.66 \%, 85.32-86.63 \%, 1.55-3.23 \%$ and $3.19-4.17 \%$, respectively. Alanine was the highest amino acid and 0.35 and $0.27 \mathrm{mg} / \mathrm{g}$ hydroxyproline was detected in $90^{\circ} \mathrm{C}$ and 10 $0^{\circ} \mathrm{C}$ VA extracts, respectively. Bacterial characterization of VA extract was also performed to identify the existing bacteria. Twelve bacteria were isolated and identified in the VA extracts with $100 \%$ identities (Chryseobacterium indologenes, Shigella flexneri ATCC 29903, Staphylococcus equorum, Staphylococcus xylosus, Vagococcus fluvialis and Staphylococcus succinus), 99\% identities (Bacillus amyloliquefaciens, Escherichia fergusonii ATCC 35469, 
Klebsiella oxytoca ATCC 13182, Macrococcus caseolyticus ATCC 13548 and Staphylococcus warneri), and 97\% identify (Mannheimia granulomatis ATCC 49244). The morphological status of $C$. indologene, $S$. flexneri ATCC 29903 and V. fluvialis was Bacilli, while Cocci was the morphology of S. equorum, S. succinus and S. xylosus.

\section{요 약}

본 연구에서는 녹용 열수 추출물의 일반성분과 지표 성분, 녹용에 존재하는 미생물을 분리 및 동정하였다. 녹용은 $90^{\circ} \mathrm{C}$ 와 $100^{\circ} \mathrm{C}$ 에서 12 시간, 24 시간, 36 시간 동안 추출하여 일반성 분과 지표 성분을 분석하였다. 일반성분분석(수분, 조단백질, 조지방, 조회분, 탄수화물)은 $\mathrm{AOAC}$ 법에 의해 측정되었고, 지표 성분(우론산, 시알산)과 아미노산은 HPLC를 이용하여 분석하였다. 또한, 배지법에 의해 녹용으로부터 분리된 미생 물을 $16 \mathrm{~s} \mathrm{rRNA}$ 염기 서열 분석을 통해 동정하였다. 추출물 의 일반성분 함량은 수분 $4.66 \%$, 조단백질 $86.63 \%$, 조지방 $3.23 \%$, 조회분 $4.1 \%$, 탄수화물 $5.43 \%$ 로 $90^{\circ} \mathrm{C}$ 에 비해 $100^{\circ} \mathrm{C}$ 에서 더 높은 함량을 보였다. 녹용 추출물의 수율은 $39.97 \%$ 로 $100^{\circ} \mathrm{C}, 36$ 시간 처리군에서 가장 높았으며 우론산과 시알 산의 함량은 $28.06 \%, 0.73 \%$ 로 각각 $90^{\circ} \mathrm{C}, 36$ 시간 처리군, $100^{\circ} \mathrm{C}, 24$ 시간 처리군에서 가장 높았다. 녹용 추출물에는 15 종의 아미노산이 고루 분포되어 있었으며 그 중 알라닌의 함 량이 가장 높았다. 또한, 녹용 추출물에서 7 개의 그람양성균(B. amyloliquefaciens, $M$. caseolyticus, $S$. equorm, S. succinus, $S$. warneri, S. xylosus, V. fluvialis $)$ 와 5개의 그람 음성균(C. indologenes, E. fergusonii, $K$. oxytoca, M. granulomatis, $S$. flexneri)가 분리 및 동정되었다.

\section{Acknowledgments}

This research was supported by the Deer Cluster (2016-A601-0001) in 2016.

\section{Conflict of interests}

The authors declare no potential conflict of interest.

\section{ORCID}

Su-Hyeon Kim https://orcid.org/0000-0001-9025-3543

Mi-Kyung Park https://orcid.org/0000-0003-1182-6046

\section{References}

Ameer K, Bae SW, Jo Y, Chung N, Gao Y, Kwon JH. Optimization and modeling for heat reflux extraction of total yield, stevioside and rebaudioside - A from Stevia rebaudiana (Bertoni) leaves. Sep Sci Technol, 52, 11931205 (2017)

AOAC. Official Methods of Analysis. 15th ed, Association of Official Analysis Chemist, Washington DC, USA, p 210 (1996)

Barbour EK, Nabbut NH, Hamadeh SK, Al-Nakhli HM. Bacterial identity and characteristics in healthy and unhealthy respiratory tracts of sheep and calves. Vet Res Commun, 21, 421-430 (1997)

Cesaretti M, Luppi E, Maccari F, Volpi N. A 96-well assay for uronic acid carbazole reaction. Carbohydr Polym, 54, 59-61 (2003)

Cheng SL, Jian YL, Chen CM, Liu BT. Relationships between antioxidants and quality characteristics from Velvet Antlers of Formosan Sambar deer. Korean J Food Sci Anim Resour, 37, 542-551 (2017)

Cooney A. A review of scientific literature on the health benefits of Velvet Antler. In: Saskatchewan: University of Saskatchewan Specialized Livestock Research Group, Department of Agricultural Economics, University of Saskatchewan, p 34 (2001)

Dhar C, Sasmal A, Varki A. From "serum sickness" to "xenosialitis": Past, present, and future significance of the non-human sialic acid Neu5Gc. Front Immunol, 10, 807 (2019)

Earnest CP, Quindry J, Panton L, Broeder C. Effect of deer antler velvet on aerobic, anaerobic and strength performance. Cent Eur J Sport Sci Med, 9, 17-26 (2015)

Garron ML, Cygler M. Structural and mechanistic classification of uronic acid-containing polysaccharide lyases. Glycobiology, 20, 1547-1573 (2010)

Huo YS, Huo H, Zhang J. The contribution of deer velvet antler research to the modern biological medicine. Chin J Integr Med, 20, 723-728 (2014)

Jang DW, Ameer K, Oh JH, Park MK. Optimization and pretreatment for hot water extraction of Korean deer (Cervus canadensis Erxleben) velvet antlers. J Microbiol Biotechnol, 30, 1116-1123 (2020)

Jeon B, Kim S, Lee S, Park P, Sung S, Kim J, Moon S. 
Effect of antler growth period on the chemical composition of velvet antler in sika deer (Cervus nippon). Mamm Biol, 74, 374-380 (2009)

Jin JH, Chun EH, Hyun JH, Choi SW, Su ST, Kim W, Kim DO, Kim BY, Baik MY. Optimization of hot water extraction and ultra high pressure extraction for deer antler. Food Sci Biotechnol, 24, 507-512 (2015)

Kim JH, Sohn HJ, Kang KI, Kim WI, An JS, Jean YH. Mycobacterium bovis infection in a farmed elk in Korea. J Vet Sci, 3, 163-166 (2002)

Kumar PN, Pammi SVN, Kollu P, Satyanarayana KVV, Shameem U. Green synthesis and characterization of silver nanoparticles using Boerhaavia diffusa plant extract and their anti bacterial activity. Ind Crops Prod, 52, 562-566 (2014)

Mignard S, Flandrois JP. 16S rRNA sequencing in routine bacterial identification: A 30-month experiment. J Microbiol Methods, 67, 574-581 (2006)

Onyeike EN, Oguike JU. Influence of heat processing methods on the nutrient composition and lipid characterization of groundnut (Arachis hypogaea) seed pastes. Biokemistri, 15, 34-43 (2003)

Pandey R, Prabhu AA, Dasu VV. Purification of recombinant human interferon gamma from fermentation broth using reverse micellar extraction: A process optimization study. Sep Sci Technol, 53, 487-495 (2018)

Park JH, Kim DW. A study on the extracting characteristics of velvet antlers using Kyenegum protease. Korea J Herbol, 26, 89-94 (2011)
Payment P, Coffin E, Paquette G. Blood agar to detect virulence factors in tap water heterotrophic bacteria. Appl Environ Microbiol, 60, 1179-1183 (1994)

Smith PK, Krohn RI, Hermanson GT, Mallia AK, Gartner FH, Provenzano MD, Fujimoto EK, Goeke NM, Olson BJ, Klenk DC. Measurement of protein using bicinchoninic acid. Anal Biochem, 150, 76-85 (1985)

Sui Z, Zhang L, Huo Y, Zhang Y. Bioactive components of velvet antlers and their pharmacological properties. $\mathrm{J}$ Pharma Biomed Anal, 87, 229-240 (2014)

Sunwoo HH, Sim LYM, Nakano T, Hudson RJ, Sim JS. Glycosaminoglycans from growing antlers of wapiti (Cervus elaphus). Can J Anim Sci, 77, 715-721 (1997)

Varki A. Sialic acids in human health and disease. Trends Mol Med, 14, 351-360 (2008)

Warren L. Sialic acid in human semen and in the male genital tract. J Clin Invest, 38, 755-761 (1959)

Zhao L, Mi Y, Guan H, Xu Y, Mei Y. Velvet antler peptide prevents pressure overload-induced cardiac fibrosis via transforming growth factor (TGF)- $\beta 1$ pathway inhibition. Eur J Pharmacol, 783, 33-46 (2016)

Zhao L, Wang X, Zhang XL, Xie QF. Purification and identification of anti-inflammatory peptides derived from simulated gastrointestinal digests of velvet antler protein (Cervus elaphus Linnaeus). J Food Drug Anal, 24, 376-384 (2016)

Zhao Y, Brasier AR. Uronic acid pathway metabolites regulate mesenchymal transition and invasiveness in lung adenocarcinoma. Biotarget, 3, 1-8 (2019) 